\title{
Nasib Target Emisi Indonesia: Pelemahan Instrumen Lingkungan Hidup di Era Pemulihan Ekonomi Nasional
}

\author{
Syaharani dan Muhammad Alfitras Tavares ${ }^{1}$
}

\begin{abstract}
Abstrak
Pandemi COVID-19 menyebabkan turunnya perekonomian Indonesia hingga 2,3\%. Selama masa pandemi, pemerintah Indonesia berupaya meningkatkan perekonomian salah satunya melalui investasi dengan mengesahkan Revisi Undang-Undang Minerba, dan Undang-Undang Cipta Kerja. Di satu sisi, peraturan ini dianggap menjadi harapan bagi pertumbuhan ekonomi. Di sisi lain, peraturan ini berpotensi merusak lingkungan dan tidak sejalan dengan komitmen pemerintah Indonesia dalam menurunkan emisi gas rumah kaca (GRK) dimana di dalamnya melemahkan instrumen perlindungan dan pengelolaan lingkungan. Padahal, Nationally Determined Contribution (NDC) Indonesia menargetkan penurunan emisi gas rumah kaca sebesar 29\% dengan Business As Usual (BAU) dan sebesar 41\% dengan bantuan internasional di tahun 2030. Pelemahan instrumen lingkungan berpotensi menyebabkan meningkatnya emisi gas rumah kaca melalui kegiatan tinggi karbon dan investasi pada energi fosil. Oleh karena itu, tulisan ini akan menganalisis secara kritis bagaimana pelemahan instrumen lingkungan dalam UU Cipta Kerja dan Revisi Undang-Undang Minerba menghambat pemenuhan target penurunan emisi gas rumah kaca Indonesia di era pemulihan ekonomi nasional.
\end{abstract}

Kata kunci: Instrumen Perlindungan dan Pengelolaan Lingkungan, Pemulihan Ekonomi Nasional, UU Cipta Kerja, UU Minerba, Target Emisi Gas Rumah Kaca.

\section{Abstract}

COVID-19 pandemic caused a decrease in the Indonesian economy by 2.3\%. During the pandemic, the Indonesian government tried to improve the economy through investment by completing the Omnibus Bill's draft and the approval of the Revised Minerba Act. Regulations that are considered able to boost the economic growth, on the other hand, have the potential to damage the environment and are not in line with the commitment of the Indonesian government in reducing greenhouse gas (GHG) emissions, which in turn cripples environmental protection and management instruments. In Indonesia's Nationally Determined Contribution (NDC), there is a target of reducing greenhouse gas emissions by $29 \%$ and $41 \%$ with international assistance from Business As Usual (BAU) in 2030. The weakening of environmental instruments can cause an increase in greenhouse gas emissions through high carbon activities and investment in fossil fuels. This paper is a critical analysis of how the crippling of environ-

\footnotetext{
${ }^{1}$ Penulis adalah mahasiswa di Fakultas Hukum Universitas Indonesia.
} 
mental instruments in the Omnibus Bill and the Revised Minerba Act hamper the fulfillment of Indonesia's GHG emission reduction targets in the era of national economic recovery.

Keywords: Environmental Protection and Management Instruments, National Economic Recovery, Omnibus Bill, Minerba Law, Greenhouse Gas Emissions Target.

\section{Pendahuluan}

Pada bulan Desember 2019, terdapat laporan mengenai adanya virus baru yang menginfeksi masyarakat yang ada di China. Dengan meningkatnya penyebaran virus tersebut, pada bulan Maret 2020 WHO mendeklarasikan Coronavirus Disease (COVID-19) sebagai suatu pandemi. ${ }^{2}$ Saat ini per Oktober 2020, telah terdapat 217 Negara yang mengonfirmasi adanya kasus COVID-19. ${ }^{3}$ Pandemi ini mengakibatkan banyak dampak negatif tak hanya dalam sektor kesehatan, namun juga pada sektor ekonomi. ${ }^{4}$ Indo- nesia juga akan mengalami penurunan ekonomi ${ }^{5}$ akibat pandemi. ${ }^{6}$ Bank Indonesia pun merevisi outlook pertumbuhan ekonomi Indonesia pada 2020 dan 2021 masing-masing menjadi 4,2\% - 4,6\% year on year (yoy) ${ }^{7}$ dan $5,2-5,6 \%{ }^{8}$

Dengan prediksi bahwa ekonomi Indonesia akan mengalami penurunan, maka Pemerintah, melakukan pengesahan terhadap Undang-Undang Nomor 3 Tahun 2020 tentang Perubahan Atas Undang-Undang Nomor 4 Tahun 2009 Tentang Pertambangan Mineral dan Batubara (UU Minerba) serta Undang-Undang

\footnotetext{
${ }^{2}$ Adityo Susilo, et al., “Coronavirus Disease 2019: Tinjauan Literatur Terkini,” Jurnal Penyakit Dalam Indonesia Vol. 7, 7 No. 1 (Maret, 2020), hlm. 45.

${ }^{3}$ Per Oktober 2020, terdapat 44 juta lebih kasus positif COVID-19 dengan jumlah kematian sebanyak 1 juta jiwa lebih. Di Indonesia sendiri terdapat lebih dari 400 ribu kasus dan jumlah kematian sebanyak lebih dari 13 ribu jiwa. Kementerian Kesehatan, “Update COVID-19,” https://covid19.kemkes.go.id/ category/situasi-infeksi-emerging/info-corona-virus/\#.X38088IzbIW, diakses tanggal 8 Oktober 2020.

${ }^{4}$ United Nations, World Economic Situation and Prospects as of mid 2020, (New York: United Nations, 2020), hlm. 1. Produk domestik bruto global (PDB) diperkirakan akan menyusut sebesar 3,2 persen pada tahun 2020. Secara kumulatif, ekonomi dunia diperkirakan akan kehilangan hampir $\$ 8,5$ triliun pada tahun 2020 dan 2021 akibat pandemi ini.

${ }^{5}$ Kementerian Keuangan, "Konferensi Pers Langkah Penguatan Perlindungan Sosial Dan Stimulus Ekonomi Menghadapi Dampak Covid-19," https://www.kemenkeu.go.id/media/14790/materi-konferensi-pers-1-april-2020.pdf, diakses tanggal 27 Juli 2020. Pertumbuhan PDB Indonesia diprediksikan tumbuh hanya $2.3 \%$ atau bahkan lebih buruk turun $-0.4 \%$.

${ }^{6}$ Ibid. Hal ini terjadi karena hilangnya pendapatan masyarakat, terjadinya penurunan daya beli masyarakat dan konsumsi, dan UMKM tidak dapat melakukan kegiatan usahanya.

${ }^{7}$ yoy atau year on year merupakan suatu metode perbandingan dalam bidang ekonomi, antara periode tahun ini dan periode yang sama di tahun sebelumnya. Dimana dilakukan untuk mengevaluasi pertumbuhan ekonomi.

${ }^{8}$ Michael Christian dan Firman Hidayat, "Dampak Coronavirus Terhadap Ekonomi Global," Perkembangan Ekonomi Keuangan dan Kerja Sama Internasional - Edisi I Bank Indonesia (Maret, 2020), hlm. 92.
} 
Cipta Kerja (UU Cipta Kerja). ${ }^{9}$ UU Minerba dan UU Cipta Kerja ini dicanangkan menjadi salah satu upaya untuk memulihkan ${ }^{10}$ dan meningkatkan ${ }^{11}$ pertumbuhan ekonomi nasional dengan cara mempermudah investasi di Indonesia. Hal ini akan berpengaruh kepada komitmen target penurunan emisi gas rumah kaca (GRK) Indonesia.

Indonesia telah berkomitmen untuk menurunkan emisi GRK pada tahun 2030 sebesar 29\% dengan kemampuan sendiri dan sampai dengan $41 \%$ bila dengan dukungan internasional. ${ }^{12}$ Dalam UU Minerba sendiri, otonomi dan kewenangan daerah dalam memberikan perizinan dan pengawasan pertambangan dihapus dan diberikan kepada Pemerintah Pusat. ${ }^{13}$ Selain itu pengesahan UU Minerba ini diprediksi akan mendorong investasi energi fosil batubara yang tinggi karbon dengan peningkatan eksplora$\mathrm{si}^{14}{ }^{14}$ dimana menjadi kontradiktif dengan target penurunan emisi GRK Indonesia. UU Cipta Kerja juga memiliki permasalahan lingkungan. Antara lain terkait pelemahan instrumen perizinan lingkungan, seperti dihapusnya istilah Izin Lingkungan dan diganti dengan istilah persetujuan lingkungan ${ }^{15}$ sehingga mengurangi esensi adanya Izin Lingkungan sebagai alat kontrol terhadap kewajiban pengelolaan lingkungan. Pelemahan perizinan lingkungan juga dapat dilihat

${ }^{9}$ Kodrat Setiawan, “Luhut Pandjaitan Ingin UU Cipta Kerja Disahkan Akhir Bulan Ini," https:// bisnis.tempo.co/read/1375783/luhut-pandjaitan-ingin-ruu-cipta-kerja-disahkan-akhir-bulan-ini/ full\&view $=$ ok, diakses tanggal 13 September 2020.

${ }^{10}$ World Bank, Indonesia Economic Prospects The Long Road To Recovery, (Jakarta: World Bank, 2020), hlm. 43.

${ }^{11}$ DPR RI, "RUU Minerba Fokus Pada Pertumbuhan Ekonomi," http://www.dpr.go.id/berita/ detail/id/27695/t/RUU+Minerba+Fokus+Pada+Pertumbuhan+Ekonomi, diakses tanggal 12 September 2020 .

${ }^{12}$ Nur Masripatin, eds., Strategi Implementasi NDC (Nationally Determined Contribution), (Jakarta: Direktorat Jenderal Pengendalian Perubahan Iklim, Kementerian Lingkungan Hidup dan Kehutanan, 2017), hlm. 1.

${ }^{13}$ Indonesian Center for Environmental Law (1), "Beberapa Kritik Hukum Terhadap Perubahan UU No. 4 Tahun 2009 Tentang Mineral Dan Batubara," Kertas Kebijakan Seri Analisis ICEL (Juni, 2020), hlm. 23.

${ }^{14}$ Dalam laporan World Bank dijelaskan bahwa revisi UU Minerba ini memberikan kewajiban bagi perusahaan pertambangan untuk melakukan aktivitas eksplorasi. Dengan adanya kewajiban tersebut, dapat menyebabkan deforestasi dan berkontribusi pada masalah polusi di Indonesia. Lihat: World Bank, Indonesia Economic Prospects The Long Road To Recovery, hlm. 67.

Revisi UU Minerba ini juga dikatakan akan meningkatkan investasi eksplorasi pertambangan batubara. Lihat: Yanita Petriella, "Mineral and Coal Mining Law: New chapter of the mining sector," https://www.pwc.com/id/en/media-centre/infrastructure-news/may-2020/mineral-and-coal-mining-law-new-chapter-of-the-mining-sector.html, diakses 30 Oktober 2020.

${ }^{15}$ Indonesia (1), Undang-Undang Cipta Kerja, UU No. 11 Tahun 2020, LN No. 245 Tahun 2020, TLN No. 6563, Ps. 21. 
pada pembatasan partisipasi di Amdal UU Cipta Kerja. ${ }^{16}$ Selain itu pengaturan mengenai strict liability dan pengaturan minimal 30\% kawasan hutan dihapus. ${ }^{17}$

Adanya pengaturan yang melemahkan instrumen lingkungan hidup dalam UU Minerba dan UU Cipta Kerja seperti yang telah dijelaskan, akan berpotensi tidak sejalan dengan target penurunan emisi GRK Indonesia. Padahal seharusnya kebijakan dalam era Pemulihan Ekonomi Nasional pasca pandemi ini, harus mendorong pemulihan dan pertumbuhan ekonomi berkelanjutan yang mengurangi kemungkinan terjadinya krisis di masa depan. ${ }^{18}$

Berangkat dari hal tersebut, naskah ini akan membahas bagaimana pelemahan instrumen lingkungan hidup yang ada dalam UU Minerba dan UU Cipta Kerja dan bagaimana kedua Undang-undang tersebut mempengaruhi pemenuhan target emisi Indonesia. Pada bagian pertama, penulisan ini akan membahas mengenai target penurunan emisi GRK Indonesia dalam Nationally Determined Contribution Indonesia dan bagaimana jumlah dari emisi GRK Indonesia. Bagian kedua dan ketiga akan membahas mengenai permasalahan pelemahan instru- men lingkungan hidup di UU Minerba dan juga UU Cipta Kerja. Bagian terakhir akan menganalisis arah kebijakan iklim Indonesia dengan pelemahan instrumen lingkungan yang didasarkan pada teori ekonomi konvensional, dimana pertumbuhan ekonomi akan berbanding lurus dengan kerusakan lingkungan, sehingga diperlukan adanya transisi ke ekonomi rendah karbon demi mencapai target emisi Indonesia dalam menghadapi perubahan iklim.

\section{Nationally Determined Contribution Indonesia dan Emisi GRK Indonesia}

Demi menjaga bumi dari perubahan iklim, negara-negara di dunia membuat suatu perjanjian tentang perubahan iklim yang bernama Paris Agreement. Perjanjian tersebut bertujuan untuk menjaga kenaikan suhu rata- rata global dengan ambang batas $2^{\circ} \mathrm{C}$ di atas tingkat di masa pra-industri dan menahan kenaikan suhu global ke $1,5^{\circ} \mathrm{C} .{ }^{19}$ Paris Agreement juga bertujuan untuk meningkatkan kemampuan adaptasi dari dampak negatif perubahan iklim, serta untuk menuju ketahanan iklim dan pembangunan yang rendah emisi. ${ }^{20}$

\footnotetext{
${ }^{16}$ Ibid., Ps. 22 angka 5.

${ }_{17}^{1}$ Ibid., Ps. 36 angka 2.

${ }^{18}$ Stockholm Environment Institute, The Economics of Low Carbon, Climate Resilient Patterns of Growth in Developing Countries: A Review of the Evidence, hlm. i.

${ }^{19}$ Perserikatan Bangsa-Bangsa, Paris Agreement on Climate Change, United Nations Framework Convention on Climate Change (2015), Ps. 2 ayat (1) huruf a.

${ }^{20}$ Ibid., Ps. 2 ayat (1) huruf b.
} 
Indonesia sendiri telah meratifikasi Paris Agreement melalui Undang -Undang Nomor 16 Tahun 2016 tentang Pengesahan Paris Agreement to the United Nations Framework Convention on Climate Change. Dengan telah diratifikasinya $\mathrm{Pa}$ ris Agreement, maka Indonesia berkomitmen untuk memenuhi target penurunan emisi GRK yang dituangkan dalam $\mathrm{Na}$ tionally Determined Contribution (NDC). Untuk melaksanakan penurunan emisi GRK tersebut, Pemerintah mengeluarkan berbagai rangkaian peraturan dan kebijakan. Dalam NDC Indonesia, Indonesia berkomitmen untuk menurunkan emisi GRK dengan target 29\% tanpa dukungan atau bantuan internasional dan sebesar $41 \%$ dengan dukungan internasional dari business as usual (BAU) pada tahun 2030. ${ }^{21}$ Dalam NDC dijelaskan tentang lima sektor yang menjadi target penurunan emisi GRK Indonesia. Sektor tersebut antara lain sektor kehutanan, energi, pertanian, industri, dan limbah. ${ }^{22}$ Hasil perhitungan inventarisasi GRK nasio- nal menunjukkan tingkat emisi GRK di tahun 2017 adalah sebesar 1.150.772 Gg $\mathrm{CO}_{2} \mathrm{e}$ dengan emisi terbesar berasal dari sektor pertanian, kehutanan dan lahan (416.297 Gg CO $2 \mathrm{e}$ ) serta energi (558.890 $\mathrm{Gg} \mathrm{CO} 2 \mathrm{e}) .{ }^{23}$ Dari data tersebut dapat dilihat bahwa Indonesia masih menghasilkan emisi yang cukup besar dari sektor energi dan kehutanan. Oleh karena itu, dalam target NDC, Indonesia berupaya untuk memaksimalkan penurunan emisi dari sektor energi dan kehutanan.

\section{Pelemahan Instrumen Lingkungan Hidup dalam UU Minerba No. 3 Ta- hun 2020}

Batubara memiliki nilai ekonomi yang tinggi bagi Indonesia. Hal ini dapat dilihat dari perkembangan produksi batubara periode tahun 2009-2018 yang mengalami peningkatan yang cukup besar, dengan capaian produksi pada tahun 2018 sebesar 557 juta ton. Dari total produksi tersebut, porsi ekspor ${ }^{24}$ batuba-

${ }^{21}$ Indonesia, First Nationally Determined Contribution of Republic of Indonesia, (Jakarta: Kementerian Lingkungan Hidup dan Kehutanan, 2016). hlm. 2.

${ }^{22}$ Ibid., hlm. 9, Table. 1.

${ }^{23}$ Dari sektor kehutanan dan kebakaran gambut sendiri nilai emisi GRK ini berasal dari tiga sumber kegiatan yaitu dekomposisi gambut sebesar $358.851 \mathrm{Gg} \mathrm{CO}_{2} \mathrm{e}$, perubahan lahan dari Non Cropland to Cropland sebesar 302.294 Gg CO 2 e, dan perubahan lahan dari Non-Otherland to Otherland sebesar 60.621 $\mathrm{Gg} \mathrm{CO}_{2} \mathrm{e}$, dimana dua kegiatan terakhir mengindikasikan adanya kegiatan deforestasi. Sedangkan dalam sektor energi Emisi GRK yang dihasilkan berasal dari kegiatan pembakaran energi/bahan bakar industri energi, manufaktur, transportasi, dan sumber-sumber lainnya seperti rumah tangga, komersial, dan Agriculture, Construction and Mining. Emisi dari kegiatan industri energi menyumbang sebesar 258,041 Gg CO 2 e, manufaktur sebesar 84,578 Gg CO 2 e, dan kegiatan transportasi sebesar 147,230 Gg $\mathrm{CO}_{2}$ e. Lihat: Indonesia, Direktorat Jenderal Pengendalian Perubahan Iklim, Kementerian Lingkungan Hidup dan Kehutanan, Laporan Inventarisasi Gas Rumah Kaca (GRK) dan Monitoring, Pelaporan, Verifikasi (MPV) Tahun 2018).

${ }^{24}$ Pendapatan batubara yang diterima oleh Negara rata-rata mencapai sekitar 31 triliun rupiah 
ra mencapai 357 juta ton $(63 \%) \cdot{ }^{25}$ Padahal, batubara merupakan salah satu penyumbang emisi GRK terparah di dunia. Pelemahan instrumen lingkungan hidup yang berfungsi mengontrol dan mencegah kerusakan lingkungan dalam UU Minerba antara lain adalah dari segi perizinan tambang dan penegakan hukum.

Penggunaan batubara sebagai energi fosil, memberikan dampak yang besar terhadap terjadinya perubahan iklim. Emisi $\mathrm{CO}_{2}$ yang dihasilkan memberikan pengaruh terhadap pemanasan global dan perubahan iklim. Pertambangan batubara juga menghasilkan emisi yaitu metana yang dilepaskan dari tambang dan emisi dari ekstraksi logam dan transportasi batubara. ${ }^{26}$

Dalam UU Minerba, terdapat pasalpasal yang cenderung sangat eksploitatif terhadap batubara dan memujurkan perusahaan tambang batubara. Isi dari Pasal tersebut antara lain adalah memberikan keringanan dan fasilitas perpajakan bagi perusahaan pertambangan, jaminan perpanjangan kontrak pertambangan, hilangnya kriteria daya dukung lingkung- an dalam penentuan wilayah izin usaha pertambangan dan sebagainya. Dengan semakin mudahnya perizinan dan adanya insentif perpajakan dari pemerintah bagi pertambangan, maka dapat dikatakan batubara masih berpotensi menjadi investasi energi yang utama, dimana pada akhirnya penggunaan batubara sebagai energi akan meningkatkan emisi GRK dan memberi dampak pada perubahan iklim.

\section{A. Perizinan Tambang}

Dalam bidang perizinan, dalam ketentuan Pasal 169 A ayat (1) UU Minerba terdapat jaminan perpanjangan otomatis bagi pemegang Kontrak Karya (KK) dan Perjanjian Karya Pengusahaan Pertambangan Batubara (PKP2B) menjadi Izin Usaha Pertambangan Khusus (IUPK). Selanjutnya dijelaskan juga, bagi perusahaan yang belum mendapatkan perpanjangan kontrak/perjanjian dijamin mendapatkan perpanjangan paling lama 2x10 tahun. Lalu perusahaan yang sudah mendapatkan perpanjangan kontrak/ perjanjian dijamin mendapatkan perpanjangan paling lama selama 10 tahun. ${ }^{27}$

(2,17 miliar USD) atau mencapai rata-rata mendekati $80 \%$ dari total pendapatan non minyak \& gas, Lihat: Institute for Essential Services Reform, Dinamika Batu Bara Indonesia: Menuju Transisi Energi yang Adil, (Jakarta: Institute for Essential Services Reform, 2019), hlm. 5.

${ }^{25}$ Dewan Energi Nasional, Outlook Energi Indonesia 2019 (Jakarta: Dewan Energi Nasional, 2019), hlm. 4 .

${ }^{26}$ Shindell, D dan G. Faluveg, "The Net Climate Impact Of Coal-Fired Power Plant Emissions," Atmospheric Chemistry and Physics (April, 2010), hlm. 3256.

${ }^{27}$ Indonesia (2), Undang-Undang Perubahan Atas Undang-Undang Nomor 4 Tahun 2009 Tentang Pertambangan Mineral Dan Batubara Minerba, UU No. 3 Tahun 2020, LN No. 147 Tahun 2020, TLN No. 6525, Ps. 169 A ayat (1). 
Negara dalam hal ini memang berwenang untuk memberikan izin dalam kegiatan ekonomi, namun perlu diingat bahwa dalam kegiatan ekonomi Indonesia juga harus berwawasan lingkungan. ${ }^{28}$ Selain itu dalam UU Minerba No. 4 Tahun 2009 juga diatur bahwa pertambangan mineral dan/atau batubara dikelola dengan asas berkelanjutan dan berwawasan lingkungan. ${ }^{29}$ Maka dari itu, dalam mengelola pertambangan khususnya batubara dan mineral, harus dilakukan dengan berwawasan lingkungan.

Di sini, seyogianya konsep perizinan masuk sebagai suatu instrumen hukum lingkungan. Perlu diingat bahwa izin merupakan adalah suatu dispensasi dari suatu larangan oleh undang-undang. ${ }^{30} \mathrm{Hal}$ ini berarti semua masyarakat sebenarnya dilarang untuk merusak lingkungan, namun apabila mendapat izin, maka diperbolehkan dengan adanya batas tertentu. Pemerintah menggunakan perizinan lingkungan untuk melindungi lingkungan dari kegiatan masyarakat. ${ }^{31}$ Namun demikian, adanya jaminan perpanjangan kontrak secara otomatis, mengakibatkan fungsi perizinan yang tadinya digunakan untuk melindungi lingkungan seakan tidak ada artinya.

Ketentuan Pasal 169 A ayat (1) tersebut tidak tepat karena dengan memberikan jaminan perpanjangan izin, maka sama saja Pemerintah tidak mematuhi asas berwawasan lingkungan dalam pembangunan ekonomi yang ada, baik dalam UUD 1945 maupun UU Minerba No. 4 Tahun 2009. Perpanjangan izin secara otomatis yang diberikan oleh Pemerintah akan bertentangan dengan konsep perizinan yang seharusnya melindungi lingkungan dan pada akhirnya akan membiarkan perusakan lingkungan di bidang pertambangan terjadi. Dengan dipermudahnya izin dalam pertambangan batubara, penggunaan batubara sebagai sumber energi akan semakin meningkat. Seperti yang diketahui bahwa pada tahun 2017 sendiri saja batubara menghasilkan emisi yang besar, yaitu dari 558.890 $\mathrm{Gg} \mathrm{CO}_{2} \mathrm{e}$ emisi GRK Indonesia yang dihasilkan dari sektor energi,

\footnotetext{
${ }^{28}$ Pasal 33 ayat (4) UUD 1945 (Amandemen Keempat) menyatakan bahwa perekonomian Indonesia didasarkan pada salah satunya asas berkelanjutan dan asas berwawasan lingkungan. Maka dari itu Indonesia telah memasukkan ketentuan mengenai perlindungan lingkungan di dalam konstitusinya, dan juga menjadikan pembangunan berkelanjutan sebagai asas dari sistem ekonominya.

${ }_{29}$ Indonesia, Undang-Undang Tentang Pertambangan Mineral dan Batubara, UU No. 4 Tahun 2009, LN No. 4 Tahun 2009, TLN. No. 4959. Penjelasan Ps. 2 huruf d menyebutkan bahwa asas berkelanjutan dan berwawasan lingkungan adalah asas yang secara terencana mengintegrasikan dimensi ekonomi, lingkungan, dan sosial budaya dalam keseluruhan usaha pertambangan mineral dari batubara untuk mewujudkan kesejahteraan masa kini dan masa mendatang. hlm. 96.

${ }^{30}$ S. Prajudi Atmosudirdjo, Hukum Administrasi Negara, cet 10 (Jakarta: Ghalia Indonesia, 1994),

${ }^{31}$ Harsanto Nursadi, eds., Hukum Administrasi Negara Sektoral, (Depok: Center for Law and Good Governance Studies dan Badan Penerbit Fakultas Hukum Universitas Indonesia, 2018), hlm. 230.
} 
sebesar $243.700 \mathrm{Gg} \mathrm{CO}_{2}$ e nya berasal dari batubara dan pembangkit listrik. ${ }^{32}$ Dengan dipermudahnya izin pertambangan, maka asas berwawasan lingkungan tidak terpenuhi. Hal ini juga akan mempermudah pengembangan industri batubara yang akan berdampak pada perubahan iklim dan menghambat transisi ke energi terbarukan.

Permasalahan dalam bidang perizinan selanjutnya adalah, dihapusnya dua kriteria penentuan Wilayah Izin Usaha Pertambangan (WIUP). Dua kriteria yang dihapus adalah kriteria daya dukung lingkungan dan tingkat kepadatan penduduk. Dalam UU Minerba, kriteria penentuan WIUP hanya rencana pengelolaan mineral dan batubara nasional, ketersediaan data sumber daya dan/atau cadangan mineral atau batubara, dan status kawasan. ${ }^{33}$ Dengan dihilangkannya pertimbangan daya dukung lingkungan dan penambahan status kawasan dalam penetapan WIUP, akan melegitimasi eksploitasi pertambangan di kawasan yang memang sudah sesuai untuk pertambangan secara legal. Namun, apabila dilihat dari kriteria daya dukung lingkungannya justru tidak akan cukup untuk mendukung kegiatan tersebut, atau bahkan telah melampaui daya dukung lingkungannya. ${ }^{34}$ Seyogianya, apabila daya dukung di suatu wilayah telah terlampaui, wilayah tersebut tidak diperuntukkan untuk dieksploitasi kembali. Pasal ini tidak berpedoman pada kaidah penataan ruang yaitu keberlanjutan dimana senantiasa menjamin kelestarian dan kelangsungan daya dukung dan daya tampung lingkungan. ${ }^{35}$ Selain itu, juga tidak berpedoman pada asas kelestarian dan keberlanjutan dalam UUPPLH. ${ }^{36}$ Maka dari itu, dapat dikatakan bahwa Pemerintah tidak menjamin kelestarian dan keberlanjutan dari lingkungan.

Dengan tidak dipenuhinya asas kelestarian dan keberlanjutan lingkungan, maka penghapusan kriteria daya dukung lingkungan pada WIUP juga tidak

\footnotetext{
${ }^{32}$ Indonesia, Direktorat Jenderal Pengendalian Perubahan Iklim, Kementerian Lingkungan Hidup dan Kehutanan, Laporan Inventarisasi Gas Rumah Kaca (GRK) dan Monitoring, Pelaporan, Verifikasi (MPV) Tahun 2018, (Jakarta: Kementerian Lingkungan Hidup dan Kehutanan, 2019), hlm. 47.

${ }^{33}$ Indonesia (2), Op. Cit., Ps. 18.

${ }^{34}$ Indonesian Center for Environmental Law (1), Op. Cit., hlm. 15.

${ }^{35}$ Indonesia, Undang-Undang Penataan Ruang, UU No. 26 Tahun 2007, LN No. 68 Tahun 2007, TLN No. 4725, Penjelasan Pasal 2 huruf c.

${ }^{36}$ Indonesia (3), Undang-Undang Perlindungan dan Pengelolaan Lingkungan Hidup, UU No. 32 Tahun 2009, LN. No. 140 Tahun 2009, TLN. No. 5059, Penjelasan Ps. 2 huruf b. Asas tersebut menyatakan bahwa setiap orang memikul kewajiban dan tanggung jawab terhadap generasi mendatang dan terhadap sesamanya dalam satu generasi dengan melakukan upaya pelestarian daya dukung ekosistem dan memperbaiki kualitas lingkungan hidup.
} 
memenuhi prinsip pembangunan berkelanjutan. ${ }^{37}$ Seharusnya daya dukung lingkungan merupakan aspek penting dalam pembangunan. Hal ini dibutuhkan untuk memastikan adanya kapasitas yang cukup bagi lingkungan untuk mendukung kehidupan manusia ${ }^{38}$ dan menjamin keutuhan lingkungan hidup, sehingga tidak mengorbankan lingkungan yang ada sekarang, dan menjamin mutu hidup generasi masa kini dan generasi masa depan.

\section{B. Penegakan Hukum}

Permasalahan lain adalah pada penegakan hukum, yaitu dihilangkannya ketentuan Pasal 165 dalam UU Minerba. Sebelumnya, Pasal 165 UU Minerba No. 4 Tahun 2009 mengatur tentang pidana penjara dan denda bagi setiap orang yang menyalahgunakan kewenangannya untuk mengeluarkan Izin Usaha Pertambangan (IUP), Izin Pertambangan Rakyat (IPR), atau Izin Usaha Pertambangan Khusus (IUPK). ${ }^{39}$ Dengan dihilangkannya ketentuan tersebut, maka setiap pejabat yang mengeluarkan IUP,
IPR dan IUPK dengan menyalahgunakan kewenangannya tidak dapat dipidana lagi. Hal ini akan meningkatkan praktik malaadministrasi, penyalahgunaan kewenangan dan peluang korupsi. Perlu diingat bahwa sektor pertambangan merupakan salah satu sumber kasus korupsi dengan nilai kerugian terbanyak. ${ }^{40}$ Dampak lain dengan dihapusnya ketentuan pidana pada Pasal 165 tersebut adalah pejabat dapat menerbitkan izin pertambangan kepada para penambang dengan mudah dan leluasa serta tidak memperhatikan syarat dan prosedur dari perizinan tersebut. Hal ini tentunya akan berakibat pada mudahnya melakukan kegiatan penambangan karena izin yang didapatkan juga mudah dan dari hasil kegiatan penambangan ini justru akan meningkatkan emisi GRK. Maka, dapat disimpulkan bahwa dari penghilangan ketentuan tersebut akan mengorbankan tidak hanya masyarakat tetapi juga lingkungan hidup. ${ }^{41}$

Selain itu, Pasal tersebut juga tidak sesuai dengan Asas Umum Pemerintah-

${ }^{37}$ Ibid., Pasal 1 angka 3 menyatakan bahwa Pembangunan berkelanjutan merupakan upaya sadar dan terencana yang memadukan aspek lingkungan hidup, sosial, dan ekonomi ke dalam strategi pembangunan untuk menjamin keutuhan lingkungan hidup serta keselamatan, kemampuan, kesejahteraan, dan mutu hidup generasi masa kini dan generasi masa depan.

${ }^{38}$ Andri Gunawan Wibisana, dan Laode M Syarif, eds., Hukum Lingkungan Teori, Legislasi dan Studi Kasus, (Jakarta: USAID, s.a), hlm. 132.

${ }^{39}$ Indonesia (2), Op. Cit., Ps. 165.

${ }^{40}$ Adi Ahdiat, "ICW: Korupsi Paling Besar 2019 Terjadi di Sektor Pertambangan,” https://kbr.id/ nasional/02-2020/icw_korupsi_paling_besar_2019_terjadi_di_sektor_pertambangan/102332.html, diakses tanggal 1 Agustus 2020.

${ }^{41}$ Indonesian Center for Environmental Law (1), Op. Cit., hlm. 29. 
an yang Baik (AUPB) yaitu asas tidak menyalahgunakan kewenangan. ${ }^{42}$ Dengan menghapus ketentuan Pasal tersebut, pejabat seakan dapat menyalahgunakan kewenangannya untuk menerbitkan izin tanpa adanya sanksi. Padahal hal tersebut dilarang dan tidak sesuai dengan asas tidak menyalahgunakan kewenangan dalam AUPB. Selain itu pejabat juga seakan mendapatkan impunitas dari Pemerintah.

Masalah lain dalam penegakan hukum dalam UU Minerba adalah adanya Pasal yang berpotensi dipakai untuk mengriminalisasi masyarakat dan aktivis yang menolak tambang yaitu Pasal 162. ${ }^{43}$ Pasal tersebut mengatur mengenai ketentuan pemberian sanksi pidana bagi setiap orang yang merintangi atau mengganggu kegiatan usaha pertambangan. Salah satu contohnya adalah kasus di Pulau Wawonii, Sulawesi Tenggara, dimana terdapat 27 warga yang menolak kehadiran tambang di pulau kecil, ${ }^{44}$ dan 3 warga diantaranya dilaporkan dengan menggunakan Pasal tersebut. ${ }^{45}$ Hal ini juga tidak sesuai dengan asas partisipatif dalam UUPPLH ${ }^{46}$ karena penolakan tambang yang dilakukan oleh warga, tidak dihiraukan oleh Pemerintah. ${ }^{47}$ Lalu, dengan adanya Pasal tersebut, dapat membatasi akses masyarakat untuk turut berpartisipasi dalam pelaksanaan perlindungan lingkungan hidup. Dimana dalam hal ini khususnya dalam melakukan mitigasi ${ }^{48}$ perubahan iklim

${ }^{42}$ Indonesia, Undang-Undang Administrasi Pemerintahan, UU No. 30 Tahun 2014, LN. No. 292 Tahun 2014, TLN. No. 5601, Penjelasan Ps. 10 ayat (1) huruf e. Asas tersebut mewajibkan setiap Badan dan/atau Pejabat Pemerintahan tidak menggunakan kewenangannya untuk kepentingan pribadi atau kepentingan yang lain dan tidak sesuai dengan tujuan pemberian kewenangan tersebut, tidak melampaui, tidak menyalahgunakan, dan/atau tidak mencampuradukkan kewenangan.

${ }^{43}$ Indonesia (2), Op. Cit., Ps. 162.

${ }^{44}$ Kamarudin, "Sulitnya Warga Wawonii Pertahankan Lahan dari Perusahaan Tambang," https:// www.mongabay.co.id/2019/09/19/sulitnya-warga-wawonii-pertahankan-lahan-dari perusahaan-tambang/ diakses 9 Oktober 2020. Para warga menolak kehadiran tambang nikel PT Gema Kreasi Perdana (GKP) karena khawatir lahan perkebunan dan alam mereka rusak karena pertambangan.

${ }^{45}$ Jaringan Advokasi Tambang, Catatan Akhir Tahun 2019 dan Proyeksi 2020, Oligarki Tambang Menghancurkan Syarat-Syarat Keselamatan Rakyat Dan Infrastruktur Ekologis di Indonesia, (Jakarta: JATAM, 2020), hlm. 16.

${ }^{46}$ Indonesia (3), Op. Cit., Penjelasan Ps. 2 huruf k. Asas tersebut menyatakan bahwa setiap anggota masyarakat didorong untuk berperan aktif dalam proses pengambilan keputusan dan pelaksanaan perlindungan dan pengelolaan lingkungan hidup, baik secara langsung maupun tidak langsung.

${ }^{47}$ Adi Briantika, "Tambang Nikel Pulau Wawonii Konawe: Ditolak Warga \& Langgar UU," https://tirto.id/tambang-nikel-pulau-wawonii-konawe-ditolak-warga-langgar-uu-elvE, diakses 30 Oktober 2020. Warga meminta pemerintah untuk mencabut izin usaha pertambangan tersebut karena melanggar hukum dan merusak lingkungan. Namun pada akhirnya tambang tersebut tetap beroperasi.

${ }^{48}$ Andri Gunawan Wibisana, dan Ladoe M Syarif, eds., Op Cit., hlm. 421. Mitigasi dalam hal perubahan iklim memiliki arti yang spesifik, yaitu upaya terkait penurunan atau pembatasan emisi gas rumah kaca (GRK), baik berupa pengurangan sumber pencemar maupun peningkatan kapasitas rosot (sinks). Penolakan terhadap pertambangan ini merupakan suatu bentuk partisipasi masyarakat untuk 
yang diakibatkan oleh emisi GRK pertambangan batubara. ${ }^{49}$ Seharusnya, warga yang menolak tersebut yang dikategorikan sebagai masyarakat terdampak, dilibatkan baik secara langsung maupun tidak langsung dalam menentukan adanya pertambangan di wilayah tempat tinggalnya, bukan malah dikriminalisasi. Maka dari itu, Pasal tersebut tidak sesuai dengan asas partisipatif, karena dapat membatasi partisipasi masyarakat dengan berpotensi mengriminalisasi masyarakat. Permasalahan lainnya ada pada Pasal 168 UU Minerba, dimana Pasal tersebut mengatur bahwa Pemerintah dapat memberikan suatu keringanan dan fasilitas perpajakan sesuai dengan ketentuan peraturan perundang-undangan, demi meningkatkan investasi di sektor pertambangan.

Dengan adanya Pasal yang melemahkan instrumen lingkungan hidup dan Pasal yang memberikan kemudahan perizinan serta fasilitas perpajakan bagi investasi di bidang pertambangan khususnya batubara, seperti yang telah dijelaskan sebelumnya, maka dapat dipastikan bahwa Pemerintah masih fokus untuk melakukan investasi di energi fosil yang tinggi karbon. Selain itu, hutan justru makin banyak yang dirusak un- tuk menggali batubara demi memenuhi kebutuhan PLTU yaitu sekitar 250 juta ton/tahun. ${ }^{50}$ Oleh karena itu pengesahan UU Minerba dengan dalih ingin memulihkan dan meningkatkan pertumbuhan ekonomi nasional justru menjadi sangat kontradiktif dengan komitmen penurunan emisi GRK yang ada pada NDC Indonesia.

\section{Pelemahan Instrumen Lingkungan Hidup dalam UU Cipta Kerja}

Penurunan ekonomi pasca pandemi mendorong pemerintah untuk melakukan upaya-upaya yang dianggap mampu untuk mendorong perekonomian Indonesia. Salah satu upaya untuk meningkatkan perekonomian pasca pandemi ialah melalui penyederhanaan regulasi dan perizinan demi meningkatkan investasi dan pertumbuhan ekonomi pasca pandemi melalui UU Cipta Kerja. Kendati dianggap mampu membawa perubahan ekonomi ke arah yang lebih baik pasca pandemi, UU Cipta Kerja memiliki banyak permasalahan dan tidak sejalan dengan komitmen penurunan emisi Indonesia. Beberapa pelemahan instrumen lingkungan hidup dalam UU Cipta Kerja antara lain:

\footnotetext{
melakukan mitigasi perubahan iklim.

${ }^{49}$ Prinsip partisipasi merupakan prinsip yang penting sebagai upaya pemberdayaan masyarakat dalam pelaksanaan pengelolaan lingkungan, dan untuk meningkatkan kualitas keputusan dan penerimaan masyarakat terhadap keputusan pemerintah yang terkait dengan lingkungan.

${ }^{50} \mathrm{Ibid}$.
} 


\section{A. Perizinan Lingkungan}

Izin Lingkungan adalah salah satu instrumen lingkungan hidup dalam UUPPLH. Izin Lingkungan pada dasarnya dibentuk karena kegiatan/usaha tidak dapat diharapkan untuk melakukan pengelolaan lingkungan secara sadar dan sukarela. ${ }^{51}$ Izin Lingkungan yang termasuk regulasi lingkungan hidup bertujuan untuk mencegah terjadinya eksternalitas. ${ }^{52}$ Pencegahan tersebut kemudian diwujudkan dalam bentuk pemberian persyaratan bagi setiap kegiatan yang berpotensi memiliki dampak penting bagi lingkungan seperti pembatasan pelepasan polutan atau produksi dan pengelolaan limbah. ${ }^{53}$ Dalam UU Cipta Kerja, istilah Izin Lingkungan dihapus dan diperkenalkan istilah Persetujuan Lingkungan sehingga menyisakan hanya satu izin tersisa dalam rezim perizinan berusaha yakni izin usaha. ${ }^{54}$ Pengaturan ini berdampak pada menurunnya esensi dari Izin Lingkungan yang tidak lagi menjadi persyaratan untuk mendapat- kan izin usaha dan melemahkan fungsi Izin Lingkungan sebagai alat kontrol terhadap kewajiban pengelolaan lingkungan suatu usaha/kegiatan. Di samping itu, UU Cipta Kerja juga tidak menjelaskan sistem pemantauan terhadap pelanggaran kegiatan/usaha yang menyebabkan dampak terhadap lingkungan. Dihapusnya bentuk Izin Lingkungan juga menghapus kesempatan publik untuk melakukan gugatan ke PTUN atas kegiatan/usaha yang dianggap merusak lingkungan. ${ }^{55}$

Selain itu, pelemahan perizinan lingkungan juga dapat dilihat pada pembatasan partisipasi publik dalam Amdal. Secara definitif, Amdal adalah dokumen yang bertujuan sebagai alat untuk merencanakan tindakan preventif terhadap kerusakan lingkungan yang mungkin timbul oleh suatu aktivitas pembangunan. ${ }^{56}$ Dapat dilihat dalam UU Cipta Kerja, hanya masyarakat terdampak saja yang dapat berpartisipasi dan partisipasi tersebut hanya terbatas dalam penyusunan

${ }^{51}$ Donna C. Rona, Environmental Permits: A Time-Saving Guide (New York: Van Nostrand Reinhold, 1988), hlm. 2-3.

${ }^{52}$ Andri Gunawan Wibisana, “Campur Tangan Pemerintah dalam Pengelolaan Lingkungan: Sebuah Penelusuran Teoretis Berdasarkan Analisis Ekonomi atas Hukum" Jurnal Hukum dan Pembangunan 47 No. 2, (2017), 177.

${ }^{53}$ OECD, “Integrated Environmental Permitting Guidelines for EECCA Countries”, 2005, tersedia pada:<http://www.oecd.org/env/outreach/35056678.pdf>, diakses pada November 2015, hlm. 12.

${ }^{54}$ Indonesia (1), Op. Cit., Ps. 21.

${ }^{55}$ UUPPLH memberikan hak kepada masyarakat untuk mengajukan pembatalan suatu izin usaha melalui keputusan pengadilan tata usaha. Lihat: Indonesia, Undang-Undang Perlindungan dan Pengelolaan Lingkungan Hidup, UU No. 32 Tahun 2009, Ps. 38. Ketentuan ini kemudian dihapus oleh Pasal 22 angka 16, UU Cipta Kerja.

${ }^{56}$ Otto Soemarwoto, Analisis Dampak Lingkungan, (Yogyakarta: Gadjah Mada University Press, 1994), hlm. 43. 
Amdal. ${ }^{57}$ Pada UUPPLH, unsur masyarakat juga mencakup pemerhati lingkungan hidup dan pihak yang terpengaruh dari keputusan dalam proses Amdal. ${ }^{58}$ Pelibatan kedua unsur tersebut bertujuan untuk meningkatkan kualitas penyusunan Amdal sebab masyarakat terdampak seringkali tidak memiliki informasi ataupun pengetahuan yang cukup terkait rencana dan dampak pembangunan tersebut bagi mereka. ${ }^{59}$ Pembatasan ini juga mempersempit pengawasan masyarakat terhadap kegiatan/usaha yang berdampak penting bagi lingkungan.

Pelemahan instrumen perizinan lingkungan dalam UU Cipta Kerja tidak mencerminkan adanya pembangunan berkelanjutan dalam pemulihan ekonomi Indonesia, sebuah konsep yang diakui dalam hukum Indonesia. ${ }^{60}$ Hal tersebut menunjukkan bahwa pengaturan dalam UU Cipta Kerja tidak menitikberatkan pada keberlangsungan lingkungan. Pengaturan dalam UU Cipta Kerja malah berpotensi membuka celah bagi kegiatan/usaha tinggi karbon dan investasi yang tidak sejalan dengan rencana penurunan emisi dan transisi adil menuju pembangunan rendah karbon.

UU Cipta Kerja juga berpotensi menjerumuskan kita ke jurang bencana ekologis melalui pelemahan instrumen lingkungan hidup yang selama ini menjadi jaring pengaman dan juga alat untuk mencegah dan mengawasi perlindungan dan pengelolaan lingkungan hidup. Hal tersebut juga ditambah dengan pengawasan terhadap pelaksanaan usaha yang melemah seiring dengan pelemahan instrumen lingkungan hidup dalam UU Cipta Kerja.

Tak hanya itu, pembatasan partisipasi masyarakat dalam menentukan suatu kebijakan dan keputusan terkait lingkungan hidup juga melanggar hak masyarakat atas partisipasi ${ }^{61}$, khususnya dalam penyusunan yang berkaitan de-

\footnotetext{
${ }^{57}$ Indonesia (1), Op. Cit., Ps. 22 angka 5.

${ }^{58}$ Indonesia (3), Op. Cit., Ps. 26.

${ }^{59}$ Indonesian Center for Environmental Law (2), Op.Cit, hlm. 8.

${ }^{60}$ Pembangunan Berkelanjutan diatur dalam beberapa instrumen hukum di Indonesia antara lain Pasal 33 ayat (4) UUD 1945 dan Pasal 2 huruf B UUPPLH. Pembangunan berkelanjutan atau pembangunan berkelanjutan dan berwawasan lingkungan pada dasarnya meletakan aspek lingkungan hidup sebagai asas dari sistem ekonominya dan mengamini adanya perwujudan pertumbuhan ekonomi dalam kerangka perlindungan lingkungan hidup. Pengaturan pembangunan berkelanjutan menunjukkan pengakuan pembangunan berkelanjutan sebagai asas hukum lingkungan. Di samping itu, pengakuan pembangunan berkelanjutan juga menunjukkan signifikansi dari prinsip tersebut sebagai tujuan dari pengaturan hukum lingkungan di Indonesia yakni untuk mewujudkan keutuhan dan pemenuhan kebutuhan generasi saat ini dan generasi yang akan datang. Lihat Andri Gunawan Wibisana, "Pembangunan Berkelanjutan: Status Hukum dan Pemaknaannya," Jurnal Hukum dan Pembangunan (2013).

${ }^{61}$ Hak atas partisipasi dalam pengambilan keputusan terkait lingkungan hidup merupakan salah satu hak yang diakui melalui prinsip mengenai partisipasi. Prinsip mengenai partisipasi sendiri merupakan prinsip lingkungan hidup yang diakui. Prinsip ini diatur dalam Pasal 10 Deklarasi Rio yang
} 
ngan tata kelola iklim. ${ }^{62}$ Hakikatnya perlindungan dan pengelolaan lingkungan hidup memerlukan sistem pengaturan yang menyeluruh, termasuk di dalamnya pilihan instrumen pengelolaan lingkungan hidup yang tepat dan komprehensif. ${ }^{63}$ Dalam pengelolaan lingkungan hidup, aspek pencegahan yang dicapai melalui perizinan lingkungan menjadi penting agar tidak terjadi dampak pencemaran dan/atau perusakan lingkungan sebab kerusakan lingkungan tentunya mengancam keberlangsungan hidup manusia baik di masa kini maupun generasi yang akan datang.

\section{B. Penegakan Hukum}

Terdapat isu lain yang juga menjadi polemik dalam UU Cipta Kerja yakni kaburnya konsep pertanggungjawaban mutlak (strict liability). Perubahan redaksional yang menghapus frasa "tanpa perlu pembuktian unsur kesalahan" sehingga normanya menjadi "Setiap orang yang tindakannya, usahanya, dan/atau kegiatannya menggunakan B3, menghasilkan dan/atau mengelola limbah B3, dan/atau yang menimbulkan ancaman serius terhadap lingkungan hidup bertanggung jawab mutlak atas kerugian yang terjadi dari usaha dan/atau kegiatannya,"64 mengaburkan makna dari strict liability itu sendiri. Hal ini menim-

menyatakan bahwa:

"....States shall facilitate and encourage public awareness and participation by making information widely available. Effective access to judicial and administrative proceedings, including redress and remedy, shall be provided [garis bawah oleh penulis]."

Hal tersebut menunjukkan bahwa negara memiliki kewajiban untuk menyediakan akses seluas-luasnya bagi masyarakat untuk mengetahui informasi terkait pengambilan keputusan terkait lingkungan hidup termasuk di dalamnya akses terhadap pengadilan dan proses administrasi. Prinsip ini merupakan salah satu prinsip penting tak hanya untuk meningkatkan kemampuan masyarakat dalam pengelolaan lingkungan tetapi juga untuk meningkatkan kualitas keputusan terkait lingkungan hidup.

Selain Deklarasi Rio, prinsip mengenai partisipasi ini juga diakui sebagai asas perlindungan dan pengelolaan lingkungan hidup di Indonesia dalam Pasal 2 huruf k UUPPLH yang mengatur bahwa setiap masyarakat diharapkan berpartisipasi aktif dalam pengambilan keputusan dan pelaksanaan perlindungan dan pengelolaan lingkungan hidup. Pembatasan akses partisipasi masyarakat dalam Amdal dan dalam mengajukan gugatan terhadap perizinan berusaha merupakan pelanggaran atas hak masyarakat untuk berpartisipasi dalam pengambilan keputusan terkait lingkungan hidup dan juga merupakan pelanggaran terhadap asas dalam hukum lingkungan yang diakui.

${ }^{62}$ Dalam penyusunan kebijakan iklim, partisipasi publik dinyatakan sebagai faktor kunci dalam membentuk kebijakan iklim yang dapat diimplementasikan dan diterima secara sosial oleh masyarakat. Partisipasi publik dalam tata kelola iklim juga dapat menghasilkan pengetahuan, meningkatkan kualitas pembuatan keputusan terkait iklim dan membina kapasitas lokal untuk menanggapi perubahan iklim termasuk mengawasi kebijakan yang dapat mempengaruhi perubahan iklim. Lihat: Sébastien Jodoin et al., "Public Participation and Climate Governance: An Introduction," Review of European Community E International Environmental Law, Vol. 24, No. 2 (2015), hlm. 120. hlm. 91.

${ }^{63}$ Alexander Kiss dan Dinah Shelton, International Environmental Law Transnational, (Pub Inc, 1991),

${ }^{64}$ Indonesia (1), Op. Cit., Ps. 22 angka 33. 
bulkan kemungkinan besar strict liability sulit untuk dibuktikan di pengadilan sebab penghapusan frasa "tanpa perlu pembuktian unsur kesalahan" mengarah pada interpretasi Hakim bahwa unsur 'kesalahan' harus dibuktikan meskipun menggunakan strict liability sebagai dasar pertanggungjawaban.

Pada praktiknya, kesalahan penafsiran strict liability pada Pasal 88 UUPPLH sebagai dasar pertanggungjawaban yang terpisah masih sering terjadi pada kasus yang mendasarkan gugatannya pada strict liability. ${ }^{65}$ Penghapusan penjelasan "tanpa perlu pembuktian unsur kesalahan" berpotensi mempersulit hakim dalam melakukan penafsiran atas strict liability. Hal ini disebabkan karena perubahan ketentuan strict liability tersebut mengaburkan perbedaan antara rezim PMH dengan strict liability, dua bentuk pertanggungjawaban yang diakui oleh UUPPLH. Padahal, selama ini strict liability telah beberapa kali digunakan dalam kasus lingkungan hidup khususnya di sektor hutan dan lahan. Strict liability digunakan untuk menjerat korporasi pembakar hutan. ${ }^{66}$ Penghapusan frasa “tanpa perlu pembuktian unsur kesalahan", apalagi dengan penafsiran dalam konteks pidana, tentunya akan semakin mempersulit hakim dalam menafsirkan strict liability dan juga membatasi penggunaan strict liability dalam kasus-kasus lingkungan hidup khususnya sektor kehutanan. Melihat pada praktiknya, strict liability merupakan ketentuan yang cukup efektif dalam menjerat para pembakar hutan. Terhambatnya penegakan hukum terhadap kasus kebakaran hutan di Indonesia tentu membuka jalan bagi peningkatan emisi dari sektor hutan dan lahan.

Hal tersebut juga diperparah dengan adanya ketentuan penghapusan minimal $30 \%$ kawasan hutan demi kemudahan pengurusan lahan dan kepentingan pembangunan dalam UU Cipta Kerja. ${ }^{67}$ Tidak adanya ambang batas minimum kawasan hutan ini berpotensi mengancam keber-

${ }^{65}$ Strict Liability seringkali disalahtafsirkan sebagai bagian dari Perbuatan Melawan Hukum (PMH) yang menghapuskan PMH secara subjektif sehingga masih dianggap perlu untuk membuktikan unsur kesalahan dari tergugat. Beberapa putusan yang menempatkan strict liability sebagai PMH antara lain Walhi $v$. Freeport (2001), Walhi $v$. Lapindo Brantas, dkk. (2007), Menteri LH v. PT Kalista Alam (2013). Lihat: Andri Gunawan Wibisana, Penegakan Hukum Lingkungan Melalui Pertanggungjawaban Perdata (Jakarta: Badan Penerbit FHUI, 2017). Naskah Akademik UU Cipta Kerja pun menempatkan dan menafsirkan strict liability sebagai bentuk pertanggungjawaban pidana sehingga unsur kesalahan harus tetap dibuktikan. Lihat: Naskah Akademik UU Cipta Kerja.

${ }^{66}$ Beberapa kasus kebakaran hutan yang mendalilkan strict liability dalam gugatannya antara lain dalam kasus Menteri LHK v. PT Nasional Sago Prima (PN Jakarta Selatan 2016), Menteri LHK v. PT Bumi Mekar Hijau (PT Palembang 2016), Menteri LHK v. PT Waringin Agro Jaya (PN Jakarta Selatan 2017) dan Menteri LHK v. PT Ricky Kurniawan Kertapersada (PT Jambi 2017).

${ }^{67}$ Indonesia (1), Op. Cit., Ps. 36 angka 2. 
langsungan lingkungan dan ekosistem ${ }^{68}$, terutama dalam konteks batas minimal tersebut dihapus untuk pembangunan. Hal ini jelas tidak sejalan dengan prinsip pembangunan berkelanjutan dan berpotensi semakin menambah panjang kasus kebakaran hutan di Indonesia. Padahal, kebakaran hutan dan deforestasi merupakan penyebab utama kebakaran hutan di Indonesia. ${ }^{69}$ Bersamaan dengan potensi terhambatnya penegakan hukum dengan dasar strict liability, pengurangan jumlah kawasan hutan serta penegakan hukum atas kebakaran hutan yang melemah maka bukan tidak mungkin jumlah emisi dari sektor kehutanan semakin meningkat akibat alih fungsi lahan.

\section{Melihat Arah Kebijakan Iklim In- donesia dalam Era Pemulihan Eko- nomi Nasional}

Penurunan terbesar emisi Indonesia diharapkan diperoleh dari dua sektor yang juga merupakan penyumbang emisi nasional terbesar yakni sektor kehu- tanan dan sektor energi dengan proyeksi penurunan emisi di sektor kehutanan sebesar $17.2 \%$ dengan kemampuan sendiri dan $23 \%$ dengan bantuan internasional sedangkan penurunan di sektor energi mencapai $11 \%$ dengan kemampuan sendiri dan $14 \%$ dengan bantuan internasional. ${ }^{70}$ Total penurunan yang diharapkan dari kedua sektor ialah sebesar $28.2 \%$ dari total emisi nasional Indonesia. ${ }^{71}$

Indonesia juga telah menerapkan beberapa kebijakan mitigasi seperti kebijakan moratorium pemberian izin baru, kebijakan satu peta, pemulihan hutan dan lahan gambut dan perhutanan sosial untuk sektor kehutanan serta mendorong pencapaian target bauran energi dan aksi efisiensi energi ${ }^{72}$ namun kebijakan tersebut belum cukup. Untuk mencapai target emisi nasional dan global, diperlukan upaya ambisius dalam mitigasi Indonesia salah satunya melalui kebijakan.

Namun demikian, faktanya, saat ini kebijakan Indonesia masih membuka ba-

\footnotetext{
${ }^{68}$ Alih fungsi kawasan hutan khususnya hutan hujan tropis menjadi perkebunan sawit dan karet mempengaruhi siklus hidrologi karena meningkatkan ET, menurunkan kemampuan infiltrasi, menurunkan tingkat arus dan di saat yang bersamaan meningkatkan intensitas banjir. Penelitian oleh Tarigan et al, menunjukkan bahwa alih fungsi hutan menyebabkan krisis air pada musim kemarau dan peningkatan frekuensi banjir d musim hujan. Untuk menjaga siklus hidrologi di daerah aliran sungai diperlukan setidaknya minimal 30\% kawasan hutan untuk memastikan efektivitas arus air di daerah aliran sungai. Lihat: Tarigan et al., "Minimum Forest Cover Required for Sustainable Water Flow Regulation of a Watershed: A Case Study in Jambi Province, Indonesia," Hydrology and Earth System Sciences 22 (2018): 590

${ }^{69}$ Wetlands International-Indonesia Programme, Seri Pengelolaan Hutan dan Lahan Gambut: Kebakaran Hutan dan Lahan, hlm. 2.

${ }^{70}$ Indonesia, Loc.Cit.

${ }^{71}$ WRI Indonesia, How can Indonesia Achieve its Climate Change Mitigation Goal? An Analysis of Potential Emissions Reductions from Energy and Land-use policies. WRI Indonesia Working Paper, 2017.

${ }^{72}$ Ibid.
} 
nyak jalan bagi kegiatan dengan intensitas karbon tinggi khususnya di sektor kehutanan dan energi. Bauran energi Indonesia masih didominasi oleh $67 \%$ energi fosil. ${ }^{73} 86 \%$ sumber listrik Indonesia berasal dari energi fosil yang didomi- nasi batubara sebanyak $50 \%{ }^{74}$ Dengan kebijakan energi yang masih bergantung pada batubara, target transisi energi menuju 23\% energi baru terbarukan pada tahun 2025 diproyeksikan tidak akan tercapai. $^{75}$

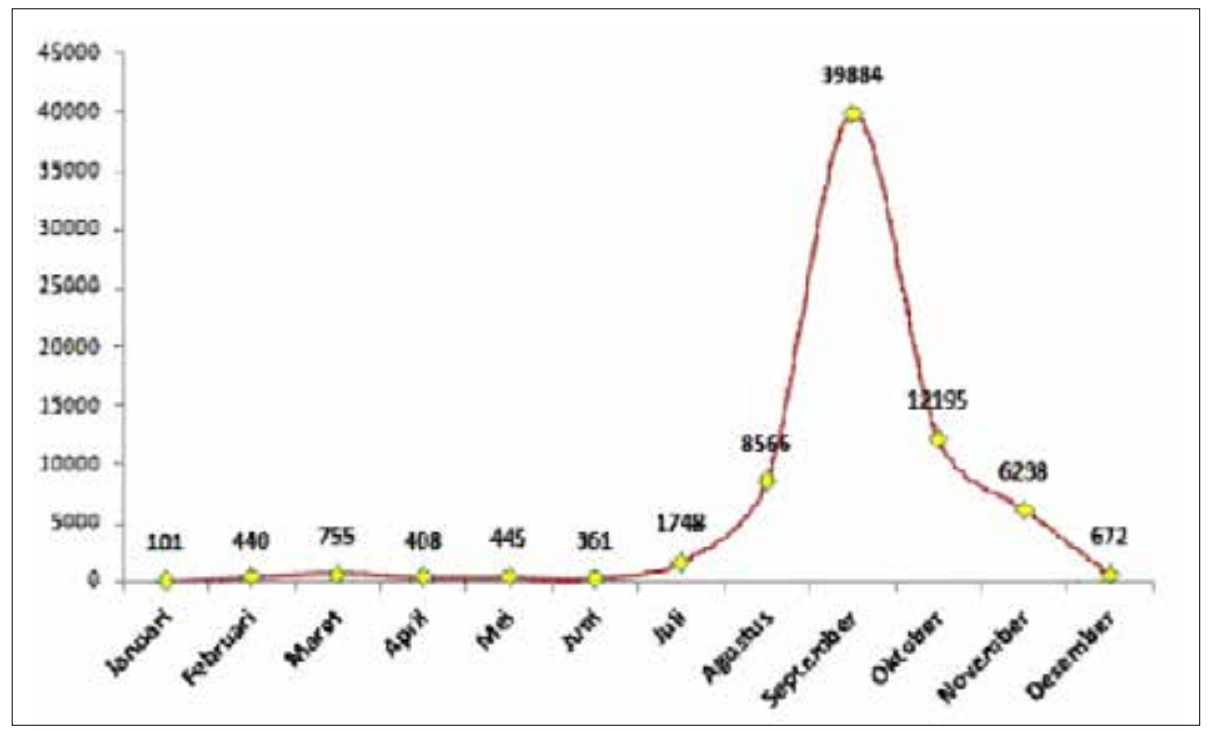

Gambar 1. Grafik Hotspot Sepanjang $2019^{76}$

Hal yang sama juga dapat dilihat pada sektor kehutanan di mana tahun 2019, periode kebakaran hutan dan lahan berlangsung dari bulan Juli sampai dengan November 2019 dengan titik puncak di bulan September 2019 di mana titik api mencapai 39884 titik. Total hutan dan lahan yang terbakar pada tahun 2019 mencapai 1.649.258 hektare, meningkat $3 x$ lipat dari jumlah kebakaran hutan dan lahan di tahun 2018 yang mencapai 529.266,64. ${ }^{77}$ Emisi dari sektor kehutanan diproyeksikan akan meningkat setidaknya sebanyak 460 sampai $510 \mathrm{MtCO}_{2} \mathrm{e} /$ tahun antara tahun 2020 dan 2030. ${ }^{78}$

${ }^{73}$ Climate Action Tracker, "Indonesia: Current Policy Projections", https://climateactiontracker. org/countries/indonesia/current-policy-projections/, diakses 1 Agustus 2020 hlm. 8.

${ }^{74}$ Dewan Energi Nasional, Outlook Energi Indonesia 2019 (Jakarta: Dewan Energi Nasional, 2019),

${ }^{75}$ Climate Action Tracker, Loc.Cit

${ }^{76}$ Walhi Indonesia, Tinjauan Lingkungan Hidup 2020 Menabur Investasi, Menuai Krisis Multidimensi, (Jakarta: Walhi, 2020), hlm. 20.

77 Indonesia, Kementerian Lingkungan Hidup dan Kehutanan, SiPongi, “Luas Kebakaran Hutan dan Lahan per Provinsi di Indonesia Tahun 2015-2020", http://sipongi.menlhk.go.id/hotspot/luas kebakaran, diakses 30 Juli 2020.

${ }^{78}$ Takashi Kuramochi, Greenhouse Gas Mitigation Scenarios for Major Emitting Countries: Analysis 
Penurunan ekonomi pasca pandemi mendorong Indonesia untuk membuka pintu seluas-luasnya bagi investasi guna mendorong kembali pertumbuhan ekonomi. Pemerintah telah merencanakan 720 triliun untuk Pemulihan Ekonomi Nasional. Akan tetapi, rencana pemulihan Indonesia tidak mempertimbangkan pemulihan hijau. ${ }^{79}$ Pelemahan instrumen lingkungan hidup melalui Perubahan UU Minerba serta UU Cipta Kerja berpeluang meningkatkan emisi gas rumah kaca Indonesia karena mendorong investasi di jalur ekonomi tinggi karbon, alih-alih melakukan transisi ke ekonomi rendah karbon. Padahal, transisi menuju ekonomi rendah karbon yang berkelanjutan yang mampu bertahan dalam krisis. ${ }^{80}$
Secara historis, krisis dapat menyebabkan penurunan jumlah emisi namun hal tersebut hanya sementara. Setelah krisis, tingkat emisi global meningkat tajam. ${ }^{81}$ Pemulihan ekonomi pasca pandemi memiliki kemungkinan untuk meningkatkan emisi gas rumah kaca secara global. ${ }^{82}$ Oleh karena itu diperlukan perubahan kebijakan struktural ke arah yang berkelanjutan. Kebijakan dalam era Pemulihan Ekonomi Nasional harus mendorong tidak hanya pemulihan ekonomi tetapi juga untuk memicu investasi yang akan mengurangi kemungkinan terjadinya krisis di masa depan dan mendorong ketahanan masyarakat akan krisis. ${ }^{83}$ Kebijakan tersebut harus sejalan dengan target jangka panjang penurunan emisi dan upaya mitigasi termasuk di dalamnya ketahanan terhadap dampak

of Current Climate Policies and Mitigation Commitmens: 2018 Update, hlm. 55.

79 Saat ini, Indonesia berencana untuk menyerahkan sebagian dana dari Rencana Pemulihan Ekonomi Nasional (PEN) kepada PLN tanpa persyaratan untuk bailout guna mengembangkan 27 GW listrik berbahan bakar batubara pada tahun 2028 di mana Indonesia adalah satu dari hanya 5 negara di dunia yang memulai pembangunan pembangkit listrik batubara (PLTU) baru d tahun 2020 dan memiliki pipa batubara terbesar dengan lebih dari total $30 \mathrm{GW}$ listrik bertenaga batubara yang berada dalam pengembangan. Hal tersebut setara dengan 6\% dari pangsa PLTU global. Lihat: Climate Action Tracker, Loc. Cit, diakses 15 Oktober 2020.

${ }^{80}$ Studi yang dilakukan Stern menunjukkan bahwa jika ekonomi belum beralih untuk memitigasi perubahan iklim, dampak yang timbul dari perubahan iklim akan merusak pertumbuhan ekonomi global. Jika tidak ada tindakan tertentu untuk menghentikan dampak perubahan iklim, keseluruhan biaya dan risiko dari perubahan iklim setara dengan pengurangan setidaknya 5\% GDP dunia setiap tahun dan bisa meningkat hingga 20\%. Lihat: Nicholas Stern, The Economics of Climate Change: The Stern Review, (Cambridge: Cambridge University Press, 2007).

${ }^{81}$ Dikutip melalui data tingkat emisi sejak tahun 1901 yang dihimpun dari berbagai penelitian oleh Global Carbon Project, ICOS, Cicero center for International Climate Research, IEA, WMO dan UK Met Office. Lihat: "The Binding Year”, Majalah Time edisi Juli 2020.

${ }^{82}$ World Resource Institute, "Responding to Coronavirus: Low Carbon Investments Can Help Economies Recover", https://www.wri.org/blog/2020/03/coronavirus-economy-low-carbon-investments, diakses 1 Agustus 2020.

${ }^{83}$ Stockholm Environment Institute, The Economics of Low Carbon, Climate Resilient Patterns of Growth in Developing Countries: A Review of the Evidence, hlm. i. 
perubahan iklim, memperlambat kepunahan keanekaragaman hayati dan meningkatkan konsep sirkularitas.

Penghapusan ketentuan 30\% minimal kawasan hutan tak hanya berpotensi menyebabkan ketidakseimbangan ekosistem tetapi juga potensi kebakaran hutan akibat pembukaan lahan. Deforestasi dan konversi semak, termasuk hutan gambut dan semak gambut, terjadi untuk memberi ruang bagi kegiatan berbasis lahan baru. Hilangnya ambang batas minimal 30\% kawasan hutan memungkinkan terjadinya deforestasi berlebihan terutama untuk kegiatan berbasis lahan. Untuk perkebunan sawit saja, akan ada 12 juta hektare deforestasi dan 9 juta hektare hutan yang dikonversi setelah 23 tahun. Jika kita mengasumsikan separuh semak merupakan lahan terdegradasi dan hutan sekunder, maka 16,5 juta hek- tare akan mengalami deforestasi setelah 23 tahun. $^{84}$ Angka tersebut belum termasuk kegiatan berbasis lahan lainnya. Pencapaian komitmen iklim di sektor kehutanan, khususnya dari pengurangan deforestasi, terancam akan gagal total karena ambang batas deforestasi pada periode 2020-2030 sebesar 3,25 juta hektare akan terlampaui pada tahun 2025. ${ }^{85}$

Hal ini ditambah dengan perubahan pasal strict liability yang mempersulit hakim untuk menafsirkan argumen dan penerapan strict liability dalam kasus kebakaran hutan. Padahal penggunaan strict liability dalam penegakan hukum terhadap kebakaran hutan mampu menekan korporasi usaha berbasis lahan untuk mencegah dan melakukan kontrol atas kebakaran hutan yang terjadi di areal kerjanya ${ }^{86}$ Kesulitan hakim untuk menafsirkan strict liability dapat mengham-

${ }^{84}$ Herry Purnomo et al., Proyeksi Sawit Indonesia: Debat Kebijakan Ekonomi, Deforestasi dan Moratorium, (Bogor: Center for International Forestry Research, 2017), hlm. 21.

${ }^{85}$ Madani Berkelanjutan, Madani Insight: Tinjauan Risiko UU Cipta Kerja terhadap Hutan Alam dan Pencapaian Komitmen Iklim Indonesia (Jakarta: Madani Berkelanjutan, 2020), hlm. 15.

${ }^{86}$ Penegakan hukum terhadap kebakaran hutan mulai dilakukan sejak 2013, di mana KLHK mulai mengajukan gugatan hukum terhadap beberapa korporasi dan menuntut mereka membayar kompensasi dan biaya pemulihan kerusakan ekologis akibat kebakaran hutan di lahan konsesinya. Dari tahun 2016 ke 2017, terdapat penurunan jumlah titik api di Indonesia sebanyak 32.6\% atau dari total 3563 titik api pada 2016 menjadi 2400 titik api pada 2017. Data tersebut menunjukkan bahwa terdapat progress signifikan pada penurunan tutupan hutan dari angka 438.360 hektare di 2016 dan 2.61 juta hektare di 2015. Meskipun faktor penegakan hukum terhadap kasus kebakaran hutan tidaklah secara tunggal berkontribusi pada penurunan jumlah kebakaran hutan dalam rentang waktu tersebut, KLHK menyatakan bahwa penurunan tersebut dipicu oleh kebijakan perhutanan dan penegakan hukum. Lihat: Asia Sentinel, "Indonesia's Jokowi Seeks to Slow Forest Fire Devastation", https:/ / www.asiasentinel. $\mathrm{com} / \mathrm{p} /$ indonesia-jokowi-seek-slow-forest-fire-devastation, diakses 15 Oktober 2020. Secara teoritis, argumen tersebut didukung oleh pandangan analisis ekonomi terhadap hukum yang menempatkan penggunaan strict liability pada tingkat yang lebih baik untuk memberikan insentif bagi pelaku usaha agar melakukan upaya kehati-hatian untuk mencegah terjadinya risiko, yang dalam hal ini ialah kebakaran hutan. Lihat: Michael G. Faure dan Roy A. Partain, Environmental Law and Economics: Theory and Practice (Cambridge: Cambridge University Press, 2019), hlm. 150. 
bat penegakan hukum bagi kebakaran hutan dan pemulihan lingkungan pasca kebakaran hutan khususnya setelah penghapusan ketentuan minimal 30\% kawasan hutan guna kebutuhan pembangunan dan lahan tentunya sangat berpotensi menambah daftar panjang kasus kebakaran hutan di Indonesia.

Meskipun secara historis emisi Indonesia didominasi oleh sektor hutan dan lahan, sektor energi diperkirakan berkontribusi lebih dari 50\% dalam emisi nasional Indonesia. Pada tahun 2017, sektor energi merupakan penyumbang emisi terbesar Indonesia. ${ }^{87}$ Indonesia berkomitmen untuk mencapai 23\% energi baru terbarukan dalam bauran energi pada tahun 2025. Akan tetapi, pelemahan instrumen lingkungan hidup dalam UU Minerba jelas menghambat pencapaian target penurunan emisi Indonesia. Pengaturan UU Minerba dinilai mampu meningkatkan nilai investasi di sektor batubara yang berarti meningkatkan penggunaan batubara ${ }^{88}$ Faktanya, sektor energi terutama batubara justru memberikan kontribusi yang besar dalam emisi GRK. Dari $558.890 \mathrm{Gg} \mathrm{CO}_{2} \mathrm{e}$ emisi GRK Indonesia tahun 2017 yang dihasilkan

${ }^{87}$ Pada Bienal Update Report Indonesia, total emisi dari sektor energi mencapai $562.244 \mathrm{Gg} \mathrm{CO}_{2} \mathrm{e}$ dibanding sektor pertanian dan hutan dan lahan yang mencapai $416.297 \mathrm{Gg} \mathrm{CO}_{2}$ e pada tahun 2017. Hal ini menunjukkan adanya pertumbuhan tingkat emisi dari sektor energi. Lihat: Indonesia, Bienal Update Report (Jakarta: Kementerian Lingkungan Hidup dan Kehutanan, 2018).

${ }^{88}$ UU Minerba mengadopsi beberapa ketentuan yang sebelumnya telah diatur oleh Peraturan Menteri Energi dan Sumber Daya Mineral No. 7 Tahun 2020 yang memberikan banyak insentif dan kemudahan berusaha bagi perusahaan batubara seperti perpanjangan otomatis bagi pemegang PKP2B. Pengaturan perizinan yang demikian, menyuburkan usaha batubara di Indonesia sehingga dipertanyakan komitmen Indonesia untuk mencapai komitmen iklim saat emisi dari sektor energi diperkirakan berkontribusi sebesar 50\% dari emisi Indonesia namun industri batubara sebagai sumber emisi terbesar sektor energi masih didukung dan dimudahkan.

Selain itu, dalam laporannya PwC menyatakan bahwa beberapa hambatan bagi investasi batubara di Indonesia antara lain disebabkan oleh tidak adanya kepastian hukum sehingga menghambat iklim investasi. Di samping itu, proses perizinan yang harus melalui tender juga membuat investasi batubara di Indonesia lambat, ditambah dengan minimnya insentif pada tingkat eksplorasi. Lihat: PwC, "Mining in Indonesia: Investment and Taxation Guide," https://www.pwc.com/id/en/energy-utilities-mining/assets/mining/mining-guide-2019.pdf, diakses 14 Oktober 2020.

Paska disahkannya UU Minerba, beberapa praktisi industri batubara memberikan respons positif terhadap pengaturan UU Minerba karena dianggap memberikan kepastian hukum dan fleksibilitas bagi pengusaha tambang batubara. Pengaturan dalam UU Minerba dianggap mampu meningkatkan capital dalam pengusahaan batubara. Lihat: CMS Law-Now, "Indonesia Updates Its Mining Law and Endeavours to Create Greater Operational Certainty," https://www.cms-lawnow.com/ealerts/2020/07/ indonesia-updates-its-mining-law-and-endeavours-to-create-greater-operational-certainty, diakses 14 Oktober 2020. Dengan demikian, dapat diekspektasikan bahwa paska berlakunya UU Minerba, tingkat investasi di sektor batubara akan mengalami pertumbuhan, yang mana berimplikasi pada ekstraksi masif dan peningkatan penggunaan batubara khususnya untuk memenuhi kebutuhan listrik $33 \mathrm{GW}$ PLTU di Indonesia yang diperkirakan akan beroperasi penuh paska 2028. Hal ini tentu menghambat perkembangan energi terbarukan di Indonesia, khususnya karena perbandingan harga yang cukup jauh meskipun saat ini pasar energi terbarukan mulai memasuki tahapan "affordable" dan menyebabkan peningkatan emisi yang dihasilkan oleh batubara. 
dari sektor energi, sebesar $243.700 \mathrm{Gg}$ $\mathrm{CO}_{2}$ e nya berasal dari batubara dan pembangkit listrik. ${ }^{89}$ Terdapat suatu prediksi bahwa akan sulit bagi Indonesia, dalam menurunkan emisi karbon hingga 29\% pada 2030, jika karbon yang dihasilkan dari pembakaran batubara, justru meningkat dua kali lipat dari 201 juta $\mathrm{tCO}_{2}$ pada 2015 menjadi 383 juta $\mathrm{tCO}_{2}$ pada 2024. ${ }^{90}$ Sebelum UU Minerba disahkan, Indonesia telah gagal mencapai target energi terbarukan dalam bauran sumber energi listrik ${ }^{91}$ yang setelah berlakunya UU Minerba akan semakin jauh dari target sebab Indonesia masih berfokus pada mendorong pertumbuhan industri batubara sebagai sumber energi utama. Di samping itu, pembatasan akses masyarakat dalam pembuatan keputusan lingkungan juga menyebabkan proses penyusunan kebijakan iklim tidak akuntabel dan tidak dapat dipantau. Masyarakat tidak dapat berpartisipasi secara penuh dalam upaya mitigasi perubahan iklim dan menghalau risiko-risiko iklim dalam kegiatan-kegiatan usaha sedangkan skenario berdasar pada kebijakan kehutanan yang telah ada saat ini menunjukkan bahwa implementasi moratorium izin hutan, restorasi gambut dan pencapaian target energi terbarukan hanya berpotensi untuk mengurangi emisi menjadi sekitar 2,311 $\mathrm{MtCO}_{2}$. Angka tersebut melebihi jumlah emisi yang ditetapkan untuk memenuhi target 29\% penurunan emisi. ${ }^{92}$ Proyeksi tersebut menyoroti betapa pentingnya memperkuat upaya dan kebijakan pemerintah demi tercapainya target penurunan emisi.

\section{Penutup}

Untuk melakukan penurunan emisi diperlukan adanya penguatan kebijakan khususnya di sektor kehutanan dan energi untuk mencapai target penurunan emisi. Implementasi penguatan kebijakan iklim Indonesia diperkirakan dapat menekan angka emisi sampai pada 1,733 $\mathrm{MtCO}_{2}$, melampaui target emisi sebesar $29 \% .^{93}$ Pada sektor kehutanan, diperlukan penguatan dan perluasan moratorium pemberian izin hutan dan lahan gambut serta pemulihan hutan dan lahan gambut yang rusak. Pemulihan 5,5 juta

\footnotetext{
${ }^{89}$ Indonesia, Direktorat Jenderal Pengendalian Perubahan Iklim, Kementerian Lingkungan Hidup dan Kehutanan, Op. Cit., hlm. 47.

${ }^{90}$ Walhi Indonesia, Tinjauan Lingkungan Hidup 2020 Menabur Investasi, Menuai Krisis Multidimensi, (Jakarta: Walhi, 2020), hlm. 41.

${ }^{91}$ Di akhir tahun 2019, total energi terbarukan yang digunakan sebagai sumber energi listrik mencapai $10.2 \mathrm{GW}$. Angka tersebut berada di bawah target pemerintah yang menyatakan akan mencapai 15.5 GW suplai listrik dari energi terbarukan pada tahun 2018. Lihat: Annisa Suharsono et al., Getting to 23 per cent: Strategies to scale up renewables in Indonesia. (Winnipeg: International Institute for Sustainable Development, 2019), hlm. 3.

${ }^{92}$ Takashi Kuramochi, Loc.Cit.

${ }^{93}$ WRI Indonesia, Loc.Cit.
} 
hektare hutan dan lahan yang terdegradasi dapat menyerap hingga $51 \mathrm{MtCO}_{2} \mathrm{e}$ per tahun pada 2030. Sedangkan untuk sektor energi, diperlukan pengembangan energi baru terbarukan untuk menekan laju emisi dari penggunaan energi dan konservasi energi. Tindakan awal untuk mempromosikan energi bersih dan menerapkan langkah-langkah konservasi energi akan menekan biaya pengurangan emisi dalam jangka panjang. Lebih jauh lagi, Indonesia perlu untuk segera mencapai net-zero emissions jika ingin mencapai komitmen iklim dalam Paris Agreement. Pencapaian tersebut dapat dilakukan melalui pembatasan penggunaan energi fosil dan menciptakan usaha berbasis lahan yang berkelanjutan.

Pelemahan instrumen lingkungan hidup untuk mendorong ekonomi tentunya bukanlah jawaban untuk menjawab krisis ekonomi yang dihadapi pasca pandemi. Diperlukan kebijakan yang mam- pu menyokong ekonomi dan kepentingan iklim seperti investasi infrastruktur bersih dalam bentuk energi terbarukan, investasi sumber daya alam untuk ketahanan dan regenerasi ekosistem termasuk pemulihan habitat-habitat yang mampu berperan sebagai carbon sinks dan menciptakan pertanian ramah iklim. ${ }^{94}$ UU Minerba serta UU Cipta Kerja yang mendorong intensifikasi kegiatan tinggi karbon akan menghambat pencapaian komitmen iklim Indonesia dan Paris Agreement. Tidak tercapainya target emisi Indonesia yang memicu perubahan iklim melanggar hak generasi saat ini dan generasi yang akan datang atas lingkungan hidup yang baik. Negara sebagai pengemban tanggung jawab untuk menjamin pemenuhan hak atas lingkungan hidup yang baik dan sehat harus membentuk kebijakan yang mampu menjamin pemenuhan hak tersebut. ${ }^{95}$ Dalam konteks perubahan iklim, kebijakan pemerintah

\section{${ }^{94}$ Ibid.}

${ }^{95}$ Indonesia (2), Op. Cit., Ps. 2 huruf a. Dalam $X$ and $Y$ v. Netherlands, EctHR berpendapat "It is clear from the interpretative practice of human rights bodies that States are not only obliged to assess potential risks to human life, but must also respond to any 'serious and substantial risk with measures 'designed to secure respect' for human rights and 'capable of protecting [those rights] - [garis bawah oleh penulis]. Dengan demikian negara tidak hanya berkewajiban untuk mengidentifikasi risiko-risiko yang mungkin mengancam hak asasi warga negaranya tetapi juga diwajibkan untuk merespons dengan mengeluarkan kebijakan yang mampu melindungi hak asasi dari risiko tersebut. Mengacu pada pendapat tersebut, Wewerinke-Singh menjelaskan dalam konteks perubahan iklim, negara tidak memiliki diskresi atau kewenangan untuk memprioritaskan kebijakan bagi perlindungan industry atau kegiatan tertentu di atas upaya mitigasi dan upaya-upaya lain yang diperlukan untuk merespons permasalahan dan risiko serius dari perubahan iklim sehingga tidak menyebabkan terlanggar atau terbatasi nya hak asasi warga negaranya akibat perubahan iklim. Oleh karena itu, negara sebagai pengemban kewajiban harusnya mengeluarkan kebijakan yang mengarah pada upaya mitigasi serius yang mampu merespons komitmen iklim global guna membatasi intensitas dampak akibat perubahan iklim. Lihat: Margaretha Wewerinke-Singh, "State Responsibility for Human Rights Violations Associated with Climate Change" di Jodoin et al (eds)., Handbook of Human Rights and Climate Governance, (Routledge, 2018). 
haruslah sejalan dengan komitmen iklim global di Paris Agreement. Oleh karena itu, perlu ditinjau kembali kebijakan Indonesia dalam era Pemulihan Ekonomi Nasional sehingga berfokus pada pembentukan kebijakan yang tidak hanya memperbaiki kondisi ekonomi semata tetapi juga membangun perekonomian yang mampu menghadapi krisis 


\section{DAFTAR PUSTAKA}

\section{Peraturan Perundang-undangan}

Indonesia. Undang-Undang Kehutanan. UU No. 41 Tahun 1999. LN.167 Tahun 1999, TLN. 3888.

Undang-Undang Penataan Ruang. UU No. 26 Tahun 2007. LN No. 68 Tahun 2007. TLN No. 4725.

Undang-Undang Tentang Pertambangan Mineral dan Batubara. UU No. 4 Tahun 2009, $\quad$ LN No. 4 Tahun 2009. TLN. No. 4959.

- Undang-Undang Perlindung-

an dan Pengelolaan Lingkungan Hidup. UU No. 32 Tahun 2009. LN No. 140 Tahun 2009. TLN No. 5059. . Undang-Undang Administrasi Pemerintahan. UU No. 30 Tahun 2014. LN. No. 292 Tahun 2014. TLN. No. 5601.

Atas Undang-Undang Nomor 4 Tahun 2009 Tentang Pertambangan Mineral Dan Batubara Minerba. UU No. 3 Tahun 2020. LN No. 147 Tahun 2020. TLN No. 6525.

. Undang-Undang Cipta Kerja, UU No. 11 Tahun 2020, LN No. 245 Tahun 2020, TLN No. 6563.

\section{Dokumen Internasional}

Perserikatan Bangsa-Bangsa. Paris Agreement on Climate Change. United Nations Framework Convention on Climate Change. (2015).

\section{Buku}

Atmosudirdjo, S. Prajudi. Hukum Administrasi Negara. cet 10 Jakarta: Ghalia Indonesia, 1994.

Faure, Michael G. dan Roy A. Partain. Environmental Law and Economics: Theory and Practice. Cambridge: Cambridge University Press, 2019.

Indonesia, Dewan Energi Nasional. Outlook Energi Indonesia 2019. Jakarta: Dewan Energi Nasional, 2019. Bienal Update Report. Jakarta: Kementerian Lingkungan Hidup dan Kehutanan, 2018.

Direktorat Jenderal Pengendalian Perubahan Iklim, Kementerian Lingkungan Hidup dan Kehutanan. Laporan Inventarisasi Gas Rumah Kaca (GRK) dan Monitoring, Pelaporan, Verifikasi (MPV) Tahun 2018. Jakarta: Kementerian Lingkungan Hidup dan Kehutanan, 2019.

First Nationally Determined Contribution of Republic of Indonesia, Jakarta: Kementerian Lingkungan Hidup dan Kehutanan, 2016.

Institute for Essential Services Reform. Dinamika Batu Bara Indonesia: Menuju Transisi Energi yang Adil. Jakarta: Institute for Essential Services Reform, 2019.

Jaringan Advokasi Tambang. Catatan Akhir Tahun 2019 dan Proyeksi 2020 , Oligarki Tambang Menghancurkan Syarat-Syarat Keselamatan Rakyat Dan In- 
frastruktur Ekologis di Indonesia, Jakarta: JATAM, 2020

Kuramochi, Takashi. Greenhouse Gas Mitigation Scenarios for Major Emitting Countries: Analysis of Current Climate Policies and Mitigation Commitmens: 2018 Update.

Masripatin, Nur. eds. Strategi Implementasi NDC (Nationally Determined Contribution). Jakarta: Direktorat Jenderal Pengendalian Perubahan Iklim, Kementerian Lingkungan Hidup dan Kehutanan, 2017.

M. Hadjon, Philipus. Pengantar Hukum Perizinan. Surabaya: Yuridika, 1993.

Nursadi, Harsanto eds. Hukum Administrasi Negara Sektoral, Depok: Center for Law and Good Governance Studies dan Badan Penerbit Fakultas Hukum Universitas Indonesia, 2018.

Soemarwoto, Otto. Analisis Dampak Lingkungan. Yogyakarta: Gadjah Mada University Press, 1994.

Stern, Nicholas. The Economics of Climate Change: The Stern Review. Cambridge: Cambridge University Press, 2007.

Stockholm Environment Institute. The Economics of Low Carbon, Climate Resilient Patterns of Growth in Developing Countries: A Review of the Evidence.

Suharsono, Annisa et al. Getting to 23 per cent: Strategies to scale up renewables in Indonesia. Winnipeg: International Institute for Sustainable Development, 2019.

Sutedi, Adrian. Hukum Perizinan dalam Sektor Pelayanan Publik. Jakarta: Sinar Grafika, 2015.
Syarif, Laode M dan Andri G. Wibisana. eds. Hukum Lingkungan Teori, Legislasi dan Studi Kasus. Jakarta: USAID, s.a.

United Nations. World Economic Situation and Prospects as of mid 2020. New York: United Nations, 2020.

Walhi Indonesia. Tinjauan Lingkungan Hidup 2020 Menabur Investasi, Menuai Krisis Multidimensi, Jakarta: Walhi, 2020.

Wewerinke-Singh, Margaretha. "State Responsibility for Human Rights Violations Associated with Climate Change" di Jodoin et al (eds). Handbook of Human Rights and Climate Governance. Routledge, 2018.

Wibisana, Andri Gunawan. Penegakan Hukum Lingkungan Melalui Pertanggungjawaban Perdata. Jakarta: Badan Penerbit FHUI, 2017.

World Bank. Indonesia Economic Prospects The Long Road To Recovery. Jakarta: World Bank, 2020.

\section{Artikel jurnal/media massa}

Christian, Michael dan Firman Hidayat, "Dampak Coronavirus Terhadap Ekonomi Global." Perkembangan Ekonomi Keuangan dan Kerja Sama Internasional -Edisi I Bank Indonesia (Maret 2020). Hlm. 87-112.

Jodoin, Sébastien, Sébastien Duyck dan Katherine Lofts. "Public Participation and Climate Governance: An Introduction." Review of European Community $\mathcal{E}$ International Environmental Law, Vol 24, No 2, 2015. 
Oxford Smith School of Enterprise and the Environment. "Will COVID-19 Fiscal Recovery Packages Accelerate or Retard Progress on Climate Change?" Oxford Review of Economic Policy 37, 2020.

Shindell, D dan G. Faluveg. "The Net Climate Impact Of Coal-Fired Power Plant Emissions." Atmospheric Chemistry and Physics (April 2010). Hlm. 3247-3260.

Susilo, Adityo, C. Martin Rumende, Ceva W Pitoyo. et al. "Coronavirus Disease 2019: Tinjauan Literatur Terkini." Jurnal Penyakit Dalam Indonesia, Vol. 7, No. 1, Maret 2020.

Tarigan et al. "Minimum Forest Cover Required for Sustainable Water Flow Regulation of a Watershed: A Case Study in Jambi Province, Indonesia." Hydrology and Earth System Sciences 22, (2018). Hlm. 581-594.

Wibisana, Andri Gunawan. "Pembangunan Berkelanjutan: Status Hukum dan Pemaknaannya". Jurnal Hukum dan Pembangunan 41, No. 1, 2013. . “Campur Tangan Pemerintah dalam Pengelolaan Lingkungan: Sebuah Penelusuran Teoretis Berdasarkan Analisis Ekonomi atas Hukum" Jurnal Hukum dan Pembangunan 47, No. 2, 2017.

WRI Indonesia. "How can Indonesia Achieve its Climate Change Mitigation Goal? An Analysis of Pote n tia 1 Emissions Reductions from Energy and Land-use policies". WRI Indonesia Working Paper, 2017.

\section{Lain-Lain}

Ahdiat, Adi. "ICW: Korupsi Paling Besar 2019 Terjadi di Sektor Pertambangan." https://kbr.id/ nasional/022020/icw_korupsi_paling_besar_2019_terjadi_di_sektor_pertambangan/102332.html. Diakses 1 Agustus 2020.

Asia Sentinel. "Indonesia's Jokowi Seeks to Slow Forest Fire Devastation." https://www.asiasentinel.com/p/ indonesia-jokowi-seek-slow-forest-fire-devastation. Diakses 15 Oktober 2020.

Climate Action Tracker. "Indonesia: Current Policy Projections." https://climateactiontracker.org/countries/indonesia/current-policy-projections/. Diakses 30 Juli 2020.

CMS Law-Now. "Indonesia Updates Its Mining Law and Endeavours to Create Greater Operational Certainty." https://www.cms-lawnow.com/ ealerts/2020/07/indonesia-updates-its-mining-law-and-endeavours-to-create-greater-operational-certainty. Diakses 14 Oktober 2020.

DPR RI. "RUU Minerba Fokus Pada Pertumbuhan Ekonomi." http:// www.dpr.go.id/berita/detail/ id/27695/t/RUU+Minerba+Fokus+ Pada+Pertumbuhan+Ekonomi. Diakses 12 September 2020.

Indonesian Center for Environmental Law. "Beberapa Kritik Hukum Terhadap Perubahan UU No. 4 Tahun 2009 Tentang Mineral Dan Batubara." Kertas Kebijakan Seri Analisis ICEL (Juni 2020). 
. "Pelemahan Instrumen Perlindungan dan Pengelolaan Lingkungan Hidup dalam UU Cipta Kerja" Kertas Kebijakan Seri Analisis ICEL (2020). Hlm. 1-20.

Kamarudin. “Sulitnya Warga Wawonii Pertahankan Lahan dari Perusahaan Tambang."https://www.mongabay. co.id/2019/09/19/sulitnya-warga-wawonii-pertahankan-lahan-dari perusahaan-tambang/. Diakses 9 Oktober 2020.

Kementerian Kesehatan. "Update COVID-19." https://covid19.kemkes.go.id/category/situasi-infeksi-emerging/info-corona-virus/\#. Xx0oNBIxXIV. Diakses 26 Juli 2020.

Kementerian Keuangan. "Konferensi Pers Langkah Penguatan Perlindungan Sosial Dan Stimulus Ekonomi Menghadapi Dampak Covid-19." https://www.kemenkeu.go.id/media/14790/materi-konferensi-pers-1-april-2020.pdf. Diakses 27 Juli 2020.
Petriella, Yanita. "Mineral and Coal Mining Law: New chapter of the mining sector." https://www.pwc.com/ id/en/media-centre/infrastructure-news/may-2020/mineral-and-coal-mining-law-new-chapter-of-the-mining-sector.html. Diakses 10 Oktober 2020.

PwC "Mining in Indonesia: Investment and Taxation Guide." https://www. pwc.com/id/en/energy-utilities-mining/assets/mining/mining-guide-2019.pdf. Diakses 14 Oktober 2020.

Setiawan, Kodrat. "Luhut Pandjaitan Ingin UU Cipta Kerja D i s a h k a n Akhir Bulan Ini." htt p s : // bisnis.tempo.co/read/1375783/ luhut-pandjaitan-ingin-ruu-cipta-kerja-disahkan-akhir-bulan-ini/ful-

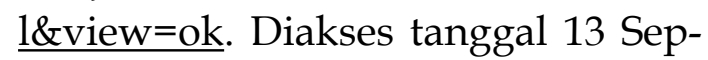
tember 2020. 